\title{
Pemetaan Normatif Logika Pengecualian Keputusan Tata Usaha Negara dalam Penyelesaian Sengketa Tata Usaha Negara
}

\author{
Anajeng Esri Edhi Mahanani \\ Fakultas Hukum, Universitas Pembangunan Nasional "Veteran" Jawa Timur \\ J1. Rungkut Madya No. 1, Gununganyar, Surabaya \\ Anajengmahanani.ih@upnjatim.ac.id
}

\begin{abstract}
Abstrak
Kompetensi absolut peradilan menjadi hal yang urgen untuk diperhatikan. Kepastian hukum untuk menghindarkan dari adanya tumpang tindih kewenangan menjadi alasan mengapa perlu dipetakan terkait keputusan tata usaha negara yang dikecualikan. Artikel ini akan membahas lebih mendalam terkait beberapa keputusan tatausaha negara yang dikecualikan menggunakan analissis deksriptif kualitatif dengan jenis penelitian yuridis normatif, menggunakan data sekunder. Dalam pembahasan ditemukan, bahwa beberapa keputusan Tata Usaha Negara dikecualikan untuk diajukan dalam penyelesaian sengketa tata usaha negara memiliki logika yuridis yang kuat, kelebihan sekaligus kelemahan yang merujuk pada perlu diadakannya rekonstruksi undang-undang administrasi negara.
\end{abstract}

Kata kunci: Kompetensi Absolut, Keputusan Tata Usaha Negara, Pengecualian

\begin{abstract}
The absolute competence of the judiciary is an urgent matter to pay attention to. Legal certainty to avoid overlapping authority is the reason why it is necessary to map out the exempted state administrative decisions. This article will discuss in more depth some of the excluded state administrative decisions using qualitative descriptive analysis with normative juridical research, using secondary data. In the discussion, it was found that several State Administration decisions that are exempted from being submitted in the settlement of state administrative disputes have strong juridical logic, both strengths, and weaknesses that refer to the need for the reconstruction of state administrative law.
\end{abstract}

Keywords: Absolute Competence, State Administration Decision, Exception

\section{A. Pendahuluan}

Hukum administrasi negara merupakan bidang ilmu hukum yang berkembang secara dinamis seiring kehidupan manusia dan pemikiran-pemikiran yang hidup didalamnya. ${ }^{1}$ Hukum administrasi negara berkembang sejalan dengan perkembangan tugas-tugas pemerintahan dan kemasyarakatan yang tentunya di sisi lain menyebabkan pertumbuhan bidang hukum administrasi negara tertentu berjalan secara sektoral.

Seiring dengan perkembangan tugas-tugas pemerintahan (ajaran welfare state) yang memberikan kewenangan yang luas kepada administrasi negara termasuk kewenangan dalam bidang legislasi, maka peraturan-peraturan hukum dalam Hukum Administrasi Negara disamping dibuat oleh lembaga legislatif, juga ada peraturan-peraturan yang dibuat secara mandiri oleh administrasi negara. Karena luasnya ruang lingkup Hukum

\footnotetext{
${ }^{1}$ Sri Rahayu Oktoberina, Niken Savitri, (Penyunting), Butir-Butir Pemikiran Dalam Hukum-Memperingati 70
} Tabun Prof.Dr.B.Arief Sidharta, S.H., Refika Aditama, Bandung, 2009, h. 29. 
Administrasi Negara, menimbulkan konsekuensi pula pada sebuah pemahaman adanya perbedaan struktur norma hukum administrasi negara dengan struktur norma dalam hukum perdata dan pidana.

Menurut H.D. Van Wijk/Willem Konijnenbelt, peraturan, norma di dalam hukum administrasi negara memiliki struktur norma yang berbeda dibandingkan dengan struktur norma yang dalam hukum perdata dan pidana serta struktur bidang hukum tertentu di luar pengaturan hukum administrasi negara. Dalam hukum administrasi negara struktur norma ditemukan pada berbagai tempat dan dalam dua atau lebih tingkatan, disana kita harus menemukan norma dan tingkatan-tingkatan peraturan hukum itu, sehingga berdasarkan kenyataan tersebut, maka dalam penegakan hukum materiil dalam hukum administrasi negara berbeda dengan penegakan hukum materiil di perdata dan pidana. $^{2}$

Suasana perbedaan struktur norma hukum administrasi negara dengan struktur norma dalam hukum perdata dan pidana serta bidang hukum lain, mau tidak mau menjadi sebuah korelasi pola hukum. Hakim peradilan administrasi negara harus memahami konsep ilmu norma, ilmu peraturan perundang-undangan dan asas-asas hukum yang merupakan bangunan daripada norma itu sendiri dalam menggunakan kewenangan yang ada padanya ketika melakukan pengujian sebuah keabsahan tindakan pemerintah dalam menerbitkan Keputusan atau Ketetapan Tata Usaha Negara yang bertentangan/melanggar peraturan perundang-undangan.

Hal ini mengingat, terdapat beberapa Keputusan Tata Usaha Negara (KTUN) yang kemudian dikecualikan untuk tidak menjadi kompetensi untuk diuji oleh hakim dalam lingkungan Peradilan Tata Usaha Negara. Terdapat hal-hal yang masuk dalam Keputusan Tata Usaha Negara namun dalam penegakan hukum-nya berbeda dengan penegakan hukum materiil tata usaha negara, disebabkan meskipun diterbitkan oleh Pejabat Administrasi Negara akan tetapi terdapat alasan maupun pembidangan hukum yang lebih tepat dalam penanganan sengketa tersebut, sehingga lebih tepat guna apabila diselesaikan dalam peradilan di luar Peradilan Tata Usaha Negara.

Bahasan mengenai pengaturan secara yuridis terkait apa saja Keputusan Tata Usaha Negara yang dikecualikan untuk tidak diuji oleh Peradilan Tata Usaha Negara, logika mengapa Keputusan tersebut dikeluarkan atau dikecualikan serta keunggulan maupun kelemahan diadakan pengecualian tersebut sampai dengan bahasan

2 Ridwan HR, Hukum Administrasi Negara, UII Press, Yogyakarta, 2003, h.96 
rekomendasi terhadap permasalahan-permasalahan yang muncul akan menjadi analisa penulis.

\section{B. Telaah Konsep}

\section{Kajian Yuridis dikeluarkannya Keputusan Tata Usaha Negara}

Berdasarkan Pasal 1 angka 9 Undang-Undang Nomor 51 Tahun 2009 tentang Perubahan Kedua atas Undang-Undang Nomor 5 Tahun 1986 tentang Peradilan Tata Usaha Negara, diperoleh definisi bahwa yang merupakan Keputusan Tata Usaha Negara adalah suatu penetapan tertulis yang dikeluarkan oleh Badan atau Pejabat Tata Usaha Negara yang berisi tindakan hukum Tata Usaha Negara yang berdasarkan peraturan perundang-undangan yang berlaku, yang bersifat konkret, individual, dan final, yang menimbulkan akibat hukum bagi seseorang atau badan hukum perdata.

Kedudukan Negara Republik Indonesia sebagai negara berdasar atas hukum (rechtstaat) bukan berdasar kekuasaan belaka (machtstaat), menuntut setiap penyelenggaraan negara berdasarkan atas hukum atau legal. Gautama mengemukakan ciri negara hukum antara lain : 1) supremacy of the law, 2) equality before the law, dan 3) constitution based on the buman right. ${ }^{3}$ Ciri sebagai supremacy of the law mengindikasikan bahwa setiap tindakan administrasi negara haruslah berdasarkan hukum yang berlaku, atau yang disebut asas legalitas. Ciri supremasi hukum dalam negara hukum, menuntut adanya sumber hukum dalam penyelengaraan pemerintahan negara dan tata usaha negara.

Dalam penyelenggaraan pemerintahan negara di Indonesia, memperhatikan konsep welfare state. Konsep welfare state ini kemudian mendorong negara dalam hal ini pemerintah yang diselenggaraakan oleh Pejabat Tata Usaha Negara untuk turut serta secara aktif dalam pergaulan kemasyarakatan, dengan maksud semakin membaca keinginan masyarakat dalam rangka mewujudkan kesejahteraannya. Administrasi negara dalam hal ini diserahi apa yang disebut .Lemaire "bestuurszorg", yang dalam bahasa Indonesia berarti penyelenggaraan kesejahteraan umum yang dilakukan pemerintah. "Bestuurszorg" meliputi segala lapangan kemasyarakatan di mana tururt serta pemerintah secara aktif dalam pergaulan manusia dirasa perlu, yang kemudian dituangkan dalam sebuah kebijakan yang dikemas secara legal dalam bentuk suatu keputusan supaya memiliki legitimasi yuridis. Hal ini menjadi tugas pemerintah yang menganut prinsip negara kesejahteraan atau "welfare state". ${ }^{4}$

\footnotetext{
${ }^{3}$ Sudargo Gautama, Pengertian Tentang Negara Hukum, Penerbit Alumni, Bandung, 1983.h. ?

${ }^{4}$ Dikutip dari Utrecht, Pengantar Hukum Administrasi Negara, Pustaka Tinta Mas, Surabaya, 1986, h.29.
} 
Secara logika yuridis, Keputusan Tata Usaha Negara dikeluarkan guna mewujudkan tujuan negara berkesejahteraan sekaligus negara berdasarkan atas hukum tersebut. Membuktikan pemerintah secara aktif menyelenggarakan pemerintahannya guna kesejahteraan rakyat dengan legitimasi hukum yang kuat melalui keputusan yang dibuatnya. Keputusan Tata Usaha Negara ini lahir atau dikeluarkan juga dalam rangka memenuhi fungsi aparat pemerintah, yakni fungsi pokok dan fungsi relatif (public service).

\section{Metode Penelitian}

Artikel ini menggunakan jenis penelitian hukum normatif, di mana mengutamakan penggunaan data sekunder, yakni data studi dokumenter. Yakni data yang kemudian dikumpulkan untuk analisis bahan kajian dalam pembahasan.

Menurut Hartono, metode penelitian ini memiliki beberapa manfaat, salah satunya guna mengenal atau mengetahui apa dan bagaimana hukum positif mengenai suatu permasalahan tertentu, serta guna mencari asas hukum, teori hukum, dan sistem hukum. ${ }^{5}$

Berdasarkan data dokumen yang telah terkumpul, penulis kemudian melakukan upaya analisis data, sebagai suatu proses pengorganisasian dan pengurutan data dalam pola, kategori, dan uraian dasar, sehingga nantinya akan ditemukan tema serta rumusan hipotesis kerja. ${ }^{6}$ Analisis data juga diartikan sebagai proses penyederhanaan data ke dalam bentuk yang lebih mudah dibaca dan diinterpretasikan. Interpretasi data dimaksudkan untuk mencari makna dan simplikasi yang lebih luas dari hasil-hasil penelitian. ${ }^{7}$

\section{Pembahasan}

\section{Logika Yuridis Keputusan Tata Usaha Negara yang Dikecualikan}

Indroharto memerinci dasar-dasar pertimbangan untuk menguji Keputusan Administrasi Negara yang dapat digugat, ke dalam empat ukuran: ${ }^{8}$

1. Bertentangan dengan Peraturan Perundang-undangan yang berlaku.

2. Melanggar larangan detournement de pouvoir.

3. Menyimpang dari nalar yang sehat (melanggar larangan willekeur).

4. Bertentangan dengan AAUPPL.

Peradilan Tata Usaha Negara menjadi wadah bagi segenap administrasi negara dalam menyelesaikan berbagai sengketa tata usaha negara. Hal ini diatur secara khusus dalam

\footnotetext{
5 Sunaryati Hartono, 2006, Penelitian Hukum di Indonesia Pada Akhir Abad Ke-20, Edisi Pertama, Alumni, Bandung, h. 140-141.

${ }^{6}$ Lexi J Moleong, 2002, Metodologi Penelitian Kualitatif. Cet. kedua, Remaja Rosdakarya, Bandung, h. 143

7 Maria SW.Sumardjono, 2014, Bahan Kuliah: Metodologi Penelitian Ilmu Hukum, Universitas Gadjah Mada, Yogyakarta, h. 32.

${ }^{8}$ Indroharto, Usaha Memahami Undang-Undang tentang Peradilan Tata Usaha Negara, Buku I, Pustaka Harapan, Jakarta 1993, h.67-68.
} 
Undang-Undang tentang Peradilan Tata Usaha Negara, seperti tertuang dalam Pasal 4 UU No.9 Tahun 2004 yang mengatur bahwa : Peradilan Tata Usaha Negara adalah salah satu pelaku kekuasaan kehakiman bagi rakyat pencari keadilan terhadap sengketa Tata Usaha Negara.

Pelaksanaan hukum acara gugatan pada Peradilan Tata Usaha Negara diatur dalam Pasal 53 Undang Undang No.9 Tahun 2004 yaitu :

(1) Orang atau badan hukum perdata yang merasa kepentingannya dirugikan oleh suatu Keputusan Tata Usaha Negara dapat mengajukan gugatan tertulis kepada pengadilan yang berwenang yang berisi tuntutan agar Keputusan Tata Usaha Negara yang disengketakan itu dinyatakan batal atau tidak sah, dengan atau tanpa disertai tuntutan ganti rugi dan/atau direhabilitasi.

(2) Alasan-alasan yang dapat digunakan dalam gugatan sebagaimana dimaksud pada ayat (1) adalah:

a. Keputusan Tata Usaha Negara yang digugat itu bertentangan dengan peraturan perundang-undangan yang berlaku;

b. Keputusan Tata Usaha Negara yang digugat itu bertentangan dengan asas-asas umum pemerintahan yang baik.

Dari ketentuan-ketentuan yuridis tersebut di atas, dapat diketahui bahwa segala sesuatu yang berkaitan dengan Keputusan Tata Usaha Negara yang disengketakan, maka diberikan wadah peradilan guna penegakan hukumnya. Akan tetapi ketentuan tersebut ternyata memiliki aturan limitatif. Dalam Hukum Tata Usaha Negara, terdapat ketentuan bahwasannya untuk Keputusan Tata Usaha Negara tertentu dikecualikan untuk diadili atau diuji oleh Pengadilan atau Pengadilan Tinggi Tata Usaha Negara.

\section{Keputusan Tata Usaha Negara yang Dikecualikan berdasar Ketentuan Undang-}

\section{Undang tentang Peradilan Administrasi}

Pasal 2 UU No. 9 Tahun 2004 tentang Perubahan Atas UU No.5 Tahun 1986 tentang Peradilan Tata Usaha Negara, mengatur bahwasannya yang dikecualikan atau yang tidak termasuk dalam pengertian Keputusan Tata Usaha Negara menurut Undang-Undang tersebut yakni:

a. Keputusan Tata Usaha Negara yang merupakan perbuatan hukum perdata;

b. Keputusan Tata Usaha Negara yang merupakan pengaturan yang bersifat umum;

c. Keputusan Tata Usaha Negara yang masih memerlukan persetujuan;

d. Keputusan Tata Usaha Negara yang dikeluarkan berdasarkan ketentuan Kitab Undang-Undang Hukum Pidana dan Kitab Undang-Undang Hukum Acara Pidana atau peraturan perundang-undangan lain yang bersifat hukum pidana;

e. Keputusan Tata Usaha Negara yang dikeluarkan atas dasar hasil pemeriksaan badan peradilan berdasarkan ketentuan peraturan perundang-undangan yang berlaku;

f. Keputusan Tata Usaha Negara mengenai tata usaha Tentara Nasional Indonesia; 
g. Keputusan Komisi Pemilihan Umum baik di pusat maupun di daerah mengenai hasil pemilihan umum.

Keputusan-keputusan yang sebenarnya dikeluarkan oleh Pejabat Tata Usaha Negara tersebut di atas dikecualikan berdasarkan logika yuridis sebagaimana yang ditemukan dalam Penjelasan Pasal 2 Undang-Undang tentang Peradilan Tata Usaha Negara, yang menyebutkan bahwa "pembatasan ini diadakan oleh karena ada beberapa jenis keputusan yang karena sifat atau maksudnya tidak dapat digolongkan dalam pengertian Keputusan Tata Usaha Negara menurut undang-undang ini". Sebagai akibatnya, Keputusan Tata Usaha Negara sebagaimana dimaksud tidak akan mungkin dapat menimbulkan sengketa Tata Usaha Negara yang menjadi ruang lingkup Peradilan Tata Usaha Negara.

\section{Logika yuridisnya adalah sebagai berikut:}

\section{a. Pasal 2 huruf a}

Dalam penjelasan diketahui bahwasannya yang dimaksud sebagai Keputusan Tata Usaha Negara yang merupakan perbuatan hukum perdata, misalnya, keputusan yang menyangkut masalah jual beli yang dilakukan antara instansi pemerintah dan perseorangan yang didasarkan pada ketentuan hukum perdata.

Untuk dapat mengerti atau memahami logika yuridis ketentuan tersebut, perlu dipahami terlebih dahulu bahwasannya memang dalam hal ini Badan atau Pejabat Tata Usaha Negara di samping dapat melakukan perbuatan hukum publik, juga memang sekaligus merupakan badan hukum perdata. Negara, Provinsi, Kabupaten atau Departemen dan sebagainya, di samping merupakan badan hukum publik, juga memang sekaligus merupakan badan hukum perdata.

Sebagai badan pemerintah, Pejabat Tata Usaha Negara yang akan melakukan perbuatan hukum perdata, selalu didahului dengan Keputusan Tata Usaha Negara yang mengatur legalisasi perbuatan hukum perdata yang hendak diselenggarakannya. Maka dari sini dapat diambil kesimpulan, apabila terjadi sengketa mengenai Keputusan Tata Usaha Negara yang dikeluarkan guna melaksanakan perbuatan perdata hendaknya menjadi kompetensi di lingkungan Peradilan Umum.

Hal ini berdasarkan logika yuridis dengan pisau analisa "teori melebur". Berdasarkan teori ini dapat dipahami bahwa Keputusan Tata Usaha Negara yang dikeluarkan oleh Badan atau Pejabat Tata Usaha Negara untuk melakukan perbuatan perdata, atau perbuatan perdata yang kemudian diikuti dengan dikeluarkannya Keputusan Tata Usaha Negara, Keputusan Tata Usaha Negara itu dianggap melebur kedalam perbuatan 
perdatanya, karena perbuatan perdata ini memang dimaksudkan agar dapat dilakukan oleh Badan atau Pejabat Tata Usaha Negara. ${ }^{9}$

\section{b. Pasal 2 huruf b}

Dalam Penjelasan dijelaskan bahwa yang dimaksud dengan "pengertian yang bersifat umum" adalah pengaturan yang memuat norma-norma hukum yang dituangkan dalam bentuk peraturan yang kekuatan berlakunya mengikat umum. Dalam hal ini Keputusan Tata Usaha Negara yang bersifat umum adalah bukan Keputusan dari Badan atau Pejabat Tata Usaha Negara yang dikeluarkan atas dasar wewenang untuk membuat peraturan perundang-undangan atau wewenang legislatif, sehingga dirasa secara logika perlu diatur pengecualian terhadap bentuk keputusan ini sebagai keputusan yang tidak dapat digugat ke PTUN. ${ }^{10}$

Logika yuridis mengapa keputusan yang bersifat umum ini dikecualikan, tentunya kembali merujuk pada bunyi Pasal 1 angka 9 UU No. 51 Tahun 2009 tentang Perubahan Kedua UU No.5 Tahun 1986 tentang Peradilan Tata Usaha Negara, bahwa yang dimaksud dengan Keputusan Tata Usaha Negara adalah suatu penetapan tertulis yang dikeluarkan oleh Badan atau Pejabat Tata Usaha Negara yang berdasarkan peraturan perundangundangan yang berlaku, yang bersifat konkret, individual, final, yang menimbulkan akibat bukum bagi seseorang atau badan hukum perdata. Dari bunyi ketentuan tersebut maka sudah dapat terlihat, secara argumen a contrario, maka yang merupakan keputusan dengan sifat umum tidak termasuk sebagai keputusan yang dimaksud dapat menjadi objek sengketa Tata Usaha Negara.

Hal ini juga mengingat bahwasannya yang dimaksud sebagai peraturan yang bersifat umum adalah peraturan yang berbentuk norma konkret, rencana, peraturan kebijaksanaan dan keputusan bersama. ${ }^{11}$ Dari sini juga terlihat bahwa yang dimasud sebagai keputusan bersifat umum tersebut lebih kepada keputusan yang dikeluarkan atas dasar wewenang untuk membuat peraturan perundang-undangan atau wewenang legislatif, bukan yang dimaksud oleh Pasal 1 angka 9 UU No. 51 Tahun 2009 tentang Perubahan Kedua UU No.5 Tahun 1986 tentang Peradilan Tata Usaha Negara.

\section{c. Pasal 2 huruf c}

\footnotetext{
${ }^{9}$ Indroharto, Op.Cit. h 117, 193-194.

10 R.Wiyono, S.H, Hukum Acara Peradilan Tata Usaha Negara: Cetakan Pertama, Sinar Grafika, Jakarta, 2007, h.31.

${ }^{11}$ Indroharto, Op.Cit.h.196
} 
Dalam Penjelasan dapat diketahui bahwa yang dimaksud dengan Keputusan Tata Usaha Negara yang masih memerlukan persetujuan adalah keputusan yang untuk dapat berlaku masih memerlukan persetujuan instansi atasan atau instansi lain. Sedangkan secara logika yuridis berdasar argumen a contrario terhadap bunyi Pasal ayat 1 angka 9 UU No. 51 Tahun 2009 tentang Perubahan Kedua UU No.5 Tahun 1986 tentang Peradilan Tata Usaha Negara yang mengartikan Keputusan Tata Usaha Negara yang dimaksud dapat sebagai objek sengketa adalah salah satunya harus bersifat final, maka dengan sendirinya Keputusan Tata Usaha Negara yang bersifat masih memerlukan persetujuan tidak termasuk sebagai keputusan yang dapat digugat sebagai objek sengketa kepada Peradilan Tata Usaha Negara.

\section{d. Pasal 2 huruf d}

Dalam Penjelasan disebutkan bahwa Keputusan Tata Usaha Negara berdasarkan ketentuan Kitab Undang-Undang Hukum Pidana seperti halnya terkait dalam perkara lalu lintas dimana Jaksa mengeluarkan perintah kepada terpidana kasus pelanggaran lalu lintas untuk melakukan sesuatu; kemudian terkait Keputusan Tata Usaha Negara berdasarkan Ketentuan Kitab Undang-Undang Hukum Acara Pidana misalnya kalau Penuntut Umum mengeluarkan surat perintah penahanan terhadap tersangka; ataupun terkait Keputusan Tata Usaha Negara berdasarkan ketentuan peraturan perundangundangan lain yang bersifat hukum pidana, umpamanya perintah jaksa untuk melakukan penyitaan barang-barang terdakwa dalam perkara tindak pidana ekonomi.

Penilaian dari segi penerapan hukumnya terhadap ketiga macam Keputusan Tata Usaha Negara tersebut dapat dilakukan hanya oleh pengadilan di lingkungan peradilan umum.

\section{e. Pasal 2 huruf e}

Keputusan Tata Usaha Negara yang dikeluarkan atas dasar hasil pemeriksaan badan peradilan berdasarkan ketentuan peraturan perundang-undangan yang berlaku, sebagaimana dimaksud pada huruf ini umpamanya:

1) Keputusan Badan Pertanahan Nasional yang mengeluarkan sertifikat tanah atas nama seseorang yang didasarkan atas pertimbangan putusan pengadilan perdata yang telah memperoleh kekuatan hukum tetap, yang menjelaskan bahwa tanah sengketa tersebut merupakan tanah negara dan tidak berstatus tanah warisan yang diperebutkan oleh para pihak.

2) Keputusan serupa angka 1, tetapi didasarkan atas amar putusan pengadilan perdata yang telah memperoleh kekuatan hukum tetap.

3) Keputusan pemecatan seorang notaris oleh Menteri yang tugas dan tanggung jawabnya meliputi jabatan notaris, setelah menerima usul Ketua Pengadilan Negeri atas dasar kewenangannya menurut ketentuan Undang-Undang Peradilan Umum. 
Logika yuridis mengapa jenis Keputusan Tata Usaha Negara tersebut di atas tidak termasuk atau dikecualikan untuk diadili dalam lingkungan peradilan Tata Usaha Negara, karena jelas bahwa keputusan yang diambil oleh Pejabat Tata Usaha Negara di atas adalah berdasarkan keputusan peradilan umum atau usulan Ketua Pengadilan Negeri di luar Peradilan Tata Usaha Negara, sehingga tidak masuk sebagai kebijakan Tata Usaha Negara yang diambil murni dengan pertimbangan berdasar bidang hukum Tata Usaha Negara.

\section{f. Pasal 2 huruf $f$}

Dalam Penjelasan memang tidak ditemukan pemaknaan lebih lanjut terkait Keputusan Tata Usaha Negara mengenai Tata Usaha Tentara Nasional Indonesia. Akan tetapi merujuk pada bunyi Pasal 3 ayat (1) TAP MPR Nomor VII/MPR/2000, dapat diketahui bahwa yang dimaksud dengan Tentara Nasional Indonesia terdiri atas Angkatan Darat, Angkatan Laut, dan Angkatan Udara.

Maka logika yuridis mengapa keputusan tersebut tidak masuk dalam Keputusan Tata Usaha Negara yang dapat diadili oleh Peradilan Tata Usaha Negara, sebab terkait Keputusan Tata Usaha Tentara Nasional Indonesia merupakan kompetensi absolut dari pengadilan di lingkungan Peradilan Militer untuk memeriksa, memutus, dan menyelesaikannya. ${ }^{12}$

\section{g. Pasal 2 huruf $g$}

Logika yuridis terkait alasan Keputusan Komisi Pemilihan Umum terhadap hasil pemilu sehingga menimbulkan sengketa tidak masuk dalam Keputusan Tata Usaha Negara yang diadili oleh Peradilan Tata Usaha Negara, sebab secra konstitusi telah jelas diatur dalam Pasal 24 C ayat (1) Undang-Undang Nomor 24 Tahun 2003, bahwa ini merupakan kompetensi absolut dari Mahkamah Konstitusi.

Hal ini juga mengingat bahwasannya hasil pemilihan umum adalah hasil perhitungan suara yang merupakan suara pemilih Warga Negara Indonesia, objek nya bukan hasil yang dikeluarkan oleh Pejabat Tata Usaha Negara. Komisi Pemilihan Umum di sini hanya bertindak sebagai lembaga yang menetapkan hasil perhitungan, bukan yang melahirkan sehingga tidak dapat digugat dalam Peradilan Tata Usaha Negara.

\section{Pengelompokan Keputusan Tata Usaha Negara yang Dikecualikan}

\footnotetext{
12 Pasal 9 Undang-Undang Nomor 31 Tahun 1997 tentang Peradilan Militer.
} 
Pengecualian terhadap Keputusan Tata Usaha Negara sehingga tidak untuk diuji atau diadili oleh Peradilan Tata Usaha Negara, dikelompokkan sebagai berikut:

1) Keputusan Tata Usaha Negara yang bersifat keperdataan;

2) Keputusan Tata Usaha Negara yang dikeluarkan dalam keadaan darurat;

3) Keputusan Tata Usaha Negara yang dikeluarkan dalam bidang Tata Usaha Tentara Nasional Indonesia;

4) Keputusan Tata Usaha Negara dalam bidang politik.

Pembahasan selanjutnya akan membahas logika yuridis mengapa keputusan-keputusan Tata Usaha Negara di atas oleh Prof.Muchsan dikecualikan untuk diadili dalam lingkungan Peradilan Tata Usaha Negara.

\section{Logika yuridisnya adalah sebagai berikut:}

\section{1) Keputusan Tata Usaha Negara yang bersifat keperdataan;}

Keputusan KTUN yang merupakan perbuatan hukum perdata, lebih bersifat kontraktual, karena bentuknya adalah perbuatan hukum yang bersegi dua (bilateral). ${ }^{13}$ Sama dengan logika yuridis yang telah dianalisa berdasar penjelasan Pasal 2 huruf a sebelumnya, Keputusan Tata Usaha Negara yang bersifat keperdataan merupakan ruang lingkup kompetensi absolut Pengadilan Negeri. Hal ini berdasarkan logika yuridis dengan pisau analisa "teori melebur". Keputusan Tata Usaha Negara itu dianggap melebur kedalam perbuatan perdatanya. Dengan kata lain, Keputusan Tata Usaha Negara ini dikeluarkan guna legalisasi perbuatan perdata oleh Pejabat atau Badan Tata Usaha Negara, sehingga apabila ada sengketa penyelesaiannya menjadi kompetensi Peradilan Umum.

\section{2) Keputusan Tata Usaha Negara yang dikeluarkan dalam keadaan darurat;}

Dalam Pasal 49 Undang-Undang Peradilan Tata Usaha Negara menyebutkan bahwa Pengadilan tidak berwenang memeriksa, memutus, dan menyelesaikan sengketa Tata Usaha Negara tertentu dalam hal keputusan yang disengketakan itu dikeluarkan:

a. Dalam waktu perang, keadaan bahaya, keadaan bencana alam, atau keadaan luar biasa yang membahayakan, berdasarkan peraturan perundang-undangan yang berlaku;

b. Dalam keadaan mendesak untuk kepentingan umum berdasarkan peraturan perundang-undangan yang berlaku.

${ }^{13}$ Muchsan, Sistem Pengawasan terhadap Perbuatan Aparat Pemerintah dan Peradilan Tata Usaha Negara di Indonesia: Cetakan Ketiga, Liberty, Yogyakarta, 2000, h. 61. 
Ketentuan tersebut menetapkan bahwasannya dalam keadaan darurat dan keadaan mendesak dilihat dari kepentingan umum, maka Keputusan Tata Usaha Negara tidak dapat dimintakan untuk diuji atau diadili.

Logika yuridisnya adalah ditinjau dari ketetuan perundang-undangan tersebut yang dimaksud keadaan darurat adalah keadaan yang perlu untuk segera ditangani dengan kebijakan pemerintah secara kilat, meskipun terkadang kebijakan tersebut tidak melalui penggodokan yang matang. Selain itu mendesak di sini juga dilihat berdasarkan kepentingan umum, yakni adalah kepentingan negara, bangsa, dan sesuai dengan perundang-undangan yang berlaku. ${ }^{14}$ Apabila terhadap Keputusan Tata Usaha Negara yang beralasan kedua alasan tersebut masih saja dapat disengketakan, bisa saja Pejabat Tata Usaha Negara yang mengeluarkan kebijakan berdasar keputusan berfikir dua kali untuk segera mengeluarkan keputusan yang mana sebenarnya apabila dikeluarkan justru berguna demi kepentingan umum.

\section{3) Keputusan Tata Usaha Negara yang dikeluarkan dalam bidang Tata Usaha} Tentara Nasional Indonesia;

Sebagaimana pembahasan logika yuridis pasal 2 huruf f, bahwa mengapa keputusan tersebut tidak masuk dalam Keputusan Tata Usaha Negara yang dapat diadili oleh Peradilan Tata Usaha Negara, sebab terkait Keputusan Tata Usaha Tentara Nasional Indonesia merupakan kompetensi absolut dari pengadilan di lingkungan Peradilan Militer untuk memeriksa, memutus, dan menyelesaikannya. ${ }^{15}$

\section{4) Keputusan Tata Usaha Negara dalam bidang politik;}

Keputusan Tata Usaha Negara dalam bidang politik seperti halnya pembubaran partai politik, dan perselisihan hasil pemilu dikecualikan untuk diuji melalui Peradilan Tata Usaha Negara sebab secara yuridis yakni dilihat dari Pasal 24 C Undang-Undang Dasar Tahun 1945, diatur bahwa mengenai hal tersebut apabila muncul sengketa diselesaikan melalui Mahkamah Konstitusi.

Secara logika yuridis hal tersebut tepat. Misal tentang sengketa keputusan yang dikeluarkan untuk memuat hasil pemilu. Hasil pemilihan umum adalah hasil perhitungan suara yang merupakan suara pemilih Warga Negara Indonesia, objek nya bukan hasil yang dikeluarkan oleh Pejabat Tata Usaha Negara. Komisi Pemilihan Umum di sini hanya bertindak sebagai lembaga yang menetapkan hasil perhitungan, bukan yang

\footnotetext{
14 W.Riawan Tjandra, Teorierraktik Peradilan Tata Usaha Negara: Edisi Revisi, Penerbit UAJY, Yogyakarta, 2010, h.29

${ }^{15}$ Undang-Undang Peradilan Militer.Op.Cit.
} 
melahirkan sehingga tidak dapat digugat dalam Peradilan Tata Usaha Negara. Begitu pula apabila tentang perselisihan dalam partai politik, pembubaran partai politik. Keputusan yang dihasilkan adalah keputusan yang didasarkan pada pembuktian internal partai politik, sehingga Keputusan yang dikeluarkan adalah Keputusan Politik, sehingga tidak masuk dalam Keputusan yang dapat diuji oleh Peradilan Tata Usaha Negara.

\section{Keunggulan dan Kelemahan adanya Pengecualian Keputusan Tata Usaha Negara untuk diadili di luar Wilayah Kompetensi Peradilan Tata Usaha Negara}

\section{Keunggulan}

a. Dibahas sebelumnya mengenai aturan pengecualian beberapa Keputusan Tata Usaha Negara serta logika yuridis mengapa keputusan tersebut dikeluarkan atau dikecualikan dari jenis-jenis Keputusan Tata Usaha Negara yang dapat diuji oleh hakim di lingkungan Peradilan Tata Usaha Negara. Berikut analisa keunggulan adanya pengecualian tersebut:

b. Kesesuaian kompetensi Peradilan Tata Usaha Negara. Pengecualian tersebut dapat memperjelas dan memberikan kepastian hukum bahwa Peradilan Tata Usaha Negara khusus untuk menyelesaikan apabila ada sengketa Tata Usaha Negara yang timbul dalam bidang tata usaha negara antara orang atau badan hukum perdata dengan pejabat tata usaha negara, baik pusat maupun daerah, sebagai akibat dikeluarkannya Keputusan Tata Usaha Negara yang dapat menjadi objek sengketa, yakni terhadap Keputusan Tata Usaha Negara yang merupakan penetapan tertulis yang dikeluarkan oleh badan atau pejabat Tata Usaha Negara yang berdasarkan peraturan perundangan-undangan yang berlaku, bersifat konkret, individual, final, serta menimbulkan akibat hukum.

c. Menghindari akibat non hukum yang bisa timbul ketika keputusan tersebut diuji di Peradilan Tata Usaha Negara. Akibat non hukum di sini, misalnya adalah akibat politis dari Keputusan Tata Usaha Negara yang dikeluarkan atas dasar pembuktian politis, atau hasil penghitungan suara pemilu, yang apabila diselesaikan melalui Peradilan Tata Usaha Negara akan berimbas mengganggu kestabilan politik upaya penyelenggaraan negara.

\section{Kelemahan}

a. Tidak ada batasan kepentingan umum dalam perundang-undangan dapat menimbulkan penyalahgunaan wewenang di badan Pejabat Tata Usaha Negara, sehingga merasa bebas karena apabila disengketakan, tidak dalam 
ranah Peradilan Tata Usaha Negara. Selama ini, belum ada produk perundang-undangan yang menjelaskan tentang kepentingan umum atau public interest. ${ }^{16}$

b. Terhindarkannya sanksi yang dapat menjerat Pejabat Tata Usaha Negara berdasar ketentuan sanksi dalam Peradilan Tata Usaha Negara, sebab sanksi yang melekat justru sanksi yang tidak berhubungan dengan administrasi negara, apabila hal tersebut diselesaikan oleh peradilan di luar PTUN.

c. Apabila sengketa terhadap objek keputusan yang menjadi salah satu keputusan yang dikecualikan tersebut tetap diuji oleh Peradilan Tata Usaha Negara karena tidak pahamnya hakim, maka akan ada tumpang tindih kewenangan.

\section{Penutup}

Keputusan Tata Usaha Negara yang dikecualikan ini sangat berhubungan dengan kompetensi absolut Peradilan Tata Usaha Negara. Perlu diberikan pemahaman, baik kepada hakim Peradilan Tata Usaha Negara maupun warga masyarakat atau badan hukum perdata (sebagai calon penggugat) terkait perihal apa saja yang menjadi kompetensi Peradilan Tata Usaha Negara, sehingga tidak akan terjadi tumpang tindih kewenangan. Diperlukan pula upaya rekonstruksi Undang-Undang Administrasi Negara, sebagai wujud kepastian hukum dalam penyelenggaraan pemerintahan. Hal ini karena undang-undang ini dapat menjadi sumber hukum materiil dalam pengujian Keputusan Tata Usaha Negara.

\section{DAFTAR PUSTAKA}

\section{Buku dan Literatur Perkuliahan:}

Gautama Sudargo, 1983. Pengertian Tentang Negara Hukum. Bandung: Penerbit Alumni HR, Ridwan, 2003. Hukum Administrasi Negara. Yogyakarta: UII Press. Indroharto, 1993. Usaha Memahami Undang-Undang tentang Peradilan Tata Usaha Negara, Buku I. Jakarta: Pustaka Harapan.

Muchsan, 2000. Sistem Pengawasan terbadap Perbuatan Aparat Pemerintah dan Peradilan Tata Usaba Negara di Indonesia: Cetakan Ketiga, Yogyakarta: Liberty.

Oktoberina, Sri Rahayu, Niken Savitri, (Penyunting), 2009. Butir-Butir Pemikiran Dalam Hukum- Memperingati 70 Tahun Prof.Dr.B.Arief Sidharta, S.H. Bandung: Refika Aditama.

Tjandra, W. Riawan,2010. Teori\& Praktik Peradilan Tata Usaba Negara: Edisi Revisi. Yogyakarta: Penerbit UAJY Press

Utrecht, 1986. Pengantar Hukum Administrasi Negara. Surabaya: Pustaka Tinta Mas.

${ }^{16}$ Prins, dalam Utrecht.Op.cit.h.151. 
Wiyono R., 2007. Hukum Acara Peradilan Tata Usaba Negara: Cetakan Pertama. Jakarta: Sinar Grafika.

\section{Perundang-Undangan:}

Undang-Undang Dasar Negara Republik Indonesia Tahun 1945.

Undang-Undang Nomor 30 Tahun Tahun 2014 tentang Administrasi Negara.

Undang-Undang Nomor 51 Tahun 2009 tentang Perubahan Kedua Undang-Undang Nomor 5 Tahun 1986 tentang Peradilan Tata Usaha Negara.

Undang-Undang Nomor 9 Tahun 2004 tentang Perubahan Atas Undang-Undang Nomor 5

Tahun 1986 tentang Peradilan Tata Usaha Negara

Undang-Undang Nomor 5 Tahun 1986 tentang Peradilan Tata Usaha Negara.

Undang-Undang Nomor 31 Tahun 1997 tentang Peradilan Militer. 